\title{
Control and possible applications of a novel carrot-spoilage basidiomycete, Fibulorhizoctonia psychrophila
}

\author{
Ronald P. de Vries · Elvira S. de Lange • \\ Han A. B. Wösten · Joost A. Stalpers
}

Received: 14 May 2007 / Accepted: 18 December 2007 / Published online: 5 January 2008

(C) The Author(s) 2008

\begin{abstract}
A novel cold-tolerant fungus, Fibulorhizoctonia psychrophila, was isolated from a refrigerated carrot storage facility and identified as an anamorph of Athelia, often classified in Rhizoctonia s.l. Growth of this fungus was observed between 0 and $20^{\circ} \mathrm{C}$ with an optimum at $9-12^{\circ} \mathrm{C}$, while incubation of mycelium grown at $15-32^{\circ} \mathrm{C}$ resulted in absence of growth even after the fungus was transferred back to $15^{\circ} \mathrm{C}$. Growth was inhibited in the presence of the antifungals sorbic acid or natamycin, in particular when the fungus was incubated at $18^{\circ} \mathrm{C}$. F . psychrophila produces polysaccharide degrading enzymes that, when compared to enzymes from the ascomycete fungus Aspergillus niger, retain a larger proportion of their activity at lower temperatures. This indicates that $F$. psychrophila could be used as a source for novel industrial enzymes that are active at $4-15^{\circ} \mathrm{C}$.
\end{abstract}

Keywords Fibulorhizoctonia psychrophila . Carrot-spoilage $\cdot$ Cold-active enzymes . Cold-tolerant fungus

R. P. de Vries $(\bowtie) \cdot$ E. S. de Lange · H. A. B. Wösten Department of Microbiology, Utrecht University, Padualaan 8, $3584 \mathrm{CH}$ Utrecht, The Netherlands e-mail: r.p.devries@uu.nl

J. A. Stalpers

CBS Fungal Biodiversity Centre, P.O. Box 85167, 3508 AD Utrecht, The Netherlands

\section{Introduction}

Fungi occupy every natural environment on earth as well as man-made indoor environments. In fact, some fungi have ecological requirements and amplitudes that are ideally suited to some artificial (human made) environments. Some of these fungi create large problems with respect to human health (e.g. Aspergillus, Candida) or to food quality (e.g. Penicillium). Among standard methodologies to prevent food spoilage are the use of preservatives and refrigeration of food. The latter method, however, is not effective when cold-tolerant spoilage fungi are present. Coldtolerant fungi are commonly found in nature and comprise species of different branches of the fungal kingdom, such as Geomyces, Leucosporidium (Panikov and Sivoza 2007), Cystofilobasidium and Mrakia (Nagakawa et al. 2004).

Cell walls form the majority of the plant biomass and consist mainly of polysaccharides. As fungi are not able to import polymeric compounds into their cells, they rely on extracellular enzyme systems for the degradation of polysaccharides into monosaccharides and short oligosaccharides. Hydrolytic enzymes acting on polysaccharides are commonly produced by fungi. These enzymes have many applications in the food and feed, paper and pulp, textile, and pharmaceutical industries and have therefore been the subject of many studies (de Vries and Visser 2001; de Vries 2003). Most of these studies and applications involve enzymes of saprophytic ascomycete 
fungi (mainly species from Aspergillus and Trichoderma) that have optimal growth temperatures between 30 and $37^{\circ} \mathrm{C}$. Consequently, most of these enzymes have optimum activities between 30 and $50^{\circ} \mathrm{C}$ and their activity rapidly decrease at lower temperatures (de Vries and Visser 2001). Efficient use of these enzymes in industrial applications is therefore often only possible by incubation above $30^{\circ} \mathrm{C}$. This not only increases production costs due to the energy required to reach this temperature, but can also cause spoilage problems, especially with respect to food and feed applications.

One of the most commonly known cold-tolerant spoilage fungi is the basidiomycete Rhizoctonia carotae (Adams and Kropp 1996; Jensen 1969; Jones and Aldwinckle 1990; Punja 1987), which is found in storage facilities of several vegetables such as carrot. Although the optimum growth-temperature of this fungus is between 15 and $20^{\circ} \mathrm{C}$ (Punja 1987), this fungus causes crater rot characterized by sunken lesions and abundant mycelial growth on carrots stored at temperatures between 1 and $4^{\circ} \mathrm{C}$. The anamorph genus Fibulorhizoctonia (Adams and Kropp 1996) (as Fibularhizoctonia) was proposed to accommodate Rhizoctonia carotae and R. centrifuga Lév (Rader 1948). The teleomorphs of these species belong to Athelia Pers., while those of the Rhizoctonia solanicomplex belong to Thanatephorus Donk, currently placed in a different order (Hibbett et al. 2007). The teleomorph of $F$. carotae was identified as Athelia arachnoidea (Berk.) Jülich (Adams and Kropp 1996). However, there is some controversion considering the scope of this species, as the name has been used for litter decomposing specimens and lichen parasites. Arvidsson (1976) concluded that the use of the name A. arachnoidea should be confined to the lichen parasite, while the material of Adams and Kropp (1996) contained only litter decomposers.

Other basidiomycete species reported from cold storage are: Corticium centrifugum (Bielenin 1986; Stalpers and Loerakker 1984; Weresub and Illman 1980), from stored apples and pears, causing fisheye rot. Although the name C. centrifugum is connected with Athelia, the species concerned differs by having constant clamps at the septa, narrower hyphae and no sclerotia, and the production of a basidiome in culture, which is now known as Butlerelfia eustacei (Weresub and Illman 1980). This species is known from Europe and North America.
In this paper we describe a new carrot-spoilage fungus, Fibulorhizoctonia psychrophila, which is a predominant species detected in refrigerated storage facilities for carrots in The Netherlands. We have analysed the cold-tolerance of this fungus and its sensitivity to commonly used fungicides. In addition, we have analysed $F$. psychrophila for production of plant polysaccharide degrading enzymes to assess its potential as a source of cold-active enzymes.

\section{Materials and methods}

Strains and growth conditions

F. psychrophila CBS 109695 (IMI 395943) was isolated as a mycelial sample by H.A.B. Wösten from a wooden crate containing Daucus carota in a refrigerated storage facility $\left(4^{\circ} \mathrm{C}\right)$ in Bant, The Netherlands in 2002. Athelia arachnoidea (Berkeley) Jülich CBS 418.72 was isolated from fallen leaf-litter of Populus sp. in The Netherlands. The type strain of Fibulorhizoctonia carotae (Rader) G.C. Adams \& Kropp CBS 464.48 and Aspergillus niger N402 were described previously (Adams and Kropp 1996; Bos et al. 1988).

F. psychrophila CBS 109695 and A. niger N402 were routinely propagated on malt extract agar and minimal medium (de Vries et al. 2004), respectively. For growth of $F$. psychrophila on carrot, potato and onion, these vegetables were ground using a coffee grinder. The vegetable pulp was used at a concentration of $10 \%$ in $1.5 \%$ agar plates in water. Liquid cultures of $F$. psychrophila and A. niger were performed in Schizophyllum commune minimal medium (Dons et al. 1979) and Aspergillus minimal medium (de Vries et al. 2004), respectively, using 1\% of a crude arabinoxylan preparation obtained from wheat after extraction of starch and proteins as the substrate. Plate cultures to determine the influence of several fungicides on growth of $F$. psychrophila were performed on malt extract agar plates. Comparison of the optimal growth temperature for $F$. psychrophila, Athelia arachnoidea and $F$. carotae was performed on malt extract agar and cherry decoction agar at temperatures of $0-27^{\circ} \mathrm{C}$ with intervals of $3^{\circ} \mathrm{C}$.

Powdered wood was obtained by grinding wood shavings of a storage crate in a coffee grinder until a fine powder was obtained. Of this powder, $1 \mathrm{~g}$ was added to $1.5 \mathrm{~g}$ agar and $100 \mathrm{ml}$ water and autoclaved 
to prepare solid media. The crude arabinoxylan preparation was a gift from Latenstein (Nijmegen, The Netherlands) and is in fact a waste stream of a protein and starch extraction process from wheat.

Molecular biology methods

Genomic DNA of CBS 109695 was extracted using the FastDNA kit (Bio 101 Systems, Q-Biogene). The 5.8S gene and flanking ITS1 and ITS2 were amplified using the primers ITS1 and ITS4 (White et al. 1990) and the sequence was deposited at genbank (Acc. Nr. EF492880). The sequence was compared with ITS sequences from $F$. carotae (U85789) and A. arachnoidea (U85791).

\section{Enzyme assays}

F. psychrophila and Aspergillus niger were grown at 15 and $30^{\circ} \mathrm{C}$, respectively in liquid medium containing a crude arabinoxylan preparation. Culture filtrate was harvested over a nylon filter after 2 days of growth and analysed for enzyme activities at 4,15 and $30^{\circ} \mathrm{C}$. Enzyme activity was determined using $p$-nitrophenyl- $\beta$ D-galactopyranoside, $\quad p$-nitrophenyl- $\beta$-D-glucopyranoside, $\quad p$-nitrophenyl- $\alpha$-D-galactopyranoside, and $p$-nitrophenyl- $\beta$-D-xylopyranoside (Sigma) as a substrate. A mixture was made consisting of $10 \mu$ culture filtrate, $50 \mu \mathrm{l} 50 \mathrm{mM}$ sodium acetate $(\mathrm{pH}$ 5.0) and $30 \mu \mathrm{l}$ sterile MiliQ water. The reactions were performed in triplicate and were started by the addition of $10 \mu \mathrm{l}$ of $0.1 \%$ stock of the $p$-nitrophenyl-linked substrate and incubated for $2 \mathrm{~h}$ at $25^{\circ} \mathrm{C}$, unless stated otherwise. The reactions were stopped by the addition of $100 \mu \mathrm{l}$ $0.25 \mathrm{M} \mathrm{Na}_{2} \mathrm{CO}_{3}$ and measured at $405 \mathrm{~nm}$ in a micro plate reader (model 550, Bio-RAD). The amount of free $p$-nitrophenol was calculated using a calibration curve.

\section{Results and discussion}

Taxonomy

Fibulorhizoctonia psychrophila Stalpers \& de Vries spec. nov. (Fig. 1).

Mycelium ad $9^{\circ} \mathrm{C}$ cotoneum, albidum, ad $18^{\circ} \mathrm{C}$ cremeum, avellaneum vel brunneum, velutinum vel crustosum. Liquor exsudatus brunneus. Sclerotia presentia vel absentia, irregularia, in statu maturitate subfusca a liquore exsiccata. Hyphae hyalinae vel subfuscae, (2.5-)3-6 $\mu \mathrm{m}$. Septa fibulatae vel afibulatae. Cellae sclerotiorum doliformes, tenui-tunicatae vel crasse-tunicatae, hyalinae vel fuscae. Fungus psychrophilus, ad temperaturas $-3^{\circ}$ ad $21^{\circ} \mathrm{C}$ crescens.

\section{Typus: CBS 109695}

Colonies at -3 to $9^{\circ} \mathrm{C}$ are cottony, rather high and reaching the lid of the Petri dish, white. Margin raised, rather dense. At increasing temperatures the mycelium grows less high and becomes nearly velvety at $18^{\circ} \mathrm{C}$ and nearly crustose at $21^{\circ} \mathrm{C}$. At $12^{\circ}$ the centre of the colony is cream-coloured, at $15^{\circ} \mathrm{C}$ becoming Light Cinnamon Drab to Avellaneous (Munsell 7.5YR6/2, 10YR6/2, 10 YR6/3). At these temperatures exudate droplets are not present. At $18^{\circ} \mathrm{C}$ the colony is low, nearly velvety, Ochraceous Tawny (7.5YR5/8) caused by exudate drops and at $21^{\circ} \mathrm{C}$ there is hardly any growth; the mycelium is crustose and Cinnamon Brown to Prouts Brown (5YR4/3, 5YR4/4), and finally Mummy Brown. Sclerotia are generally not produced within 6 weeks, but have occurred in a tube; they start as white semiglobose pustules, generally up to $1 \mathrm{~mm}$ diameter, aggregated, often fusing, and producing a brown exudate, which dries in, leaving a dark brown sclerotium, up to $5 \mathrm{~mm}$ diam, finally Mummy Brown.

Marginal hyphae at -3 to $3^{\circ} \mathrm{C}$ are irregular, rather long-celled, with swellings and granular contents, thinwalled, (2.5-)3-6 $\mu \mathrm{m}$ wide, swellings up to $12 \mu \mathrm{m}$ wide. Clamps present, not abundant. Branching at various angles, sometimes a constriction is present at the base of the side branch. At $6^{\circ} \mathrm{C}$ and above the hyphae are regular, thin- to firm-walled, 2.5-6(-7.5) $\mu \mathrm{m}$ wide, contents hyaline to pale brownish, with abundant clamps, especially at the wider hyphae, but the narrower hyphae (2.5-3.4-4 $\mu \mathrm{m})$ generally have clampless septa. Cell wall hyaline, but irregular brownish encrustations present at some hyphae, probably dried exudate.

Aerial mycelium regular, thin- to firm-walled, (2.5-)3.2-6.5 $\mu \mathrm{m}$ wide, with hyaline to brownish contents. Most septa with clamps; clamps regular, but sometimes of the medallion type.

Sclerotia rarely produced, uniform, not forming a distinct cortex, consisting of thin- to thick-walled hyphae, usually consisting of slightly elongated swollen cells with granular contents, 4-10 $\mu \mathrm{m}$ wide, not unlike the (thin-walled) advancing hyphae at lower temperatures. 
Fig. 1 Colony morphology of Fibulorhizoctonia carotae (464.84), Athelia arachnoidea (418.72) and Fibulorhizoctonia psychrophila (109659) after 2 weeks. (a) $0^{\circ} \mathrm{C}$; (b) $6^{\circ} \mathrm{C}$; (c) $18^{\circ} \mathrm{C}$
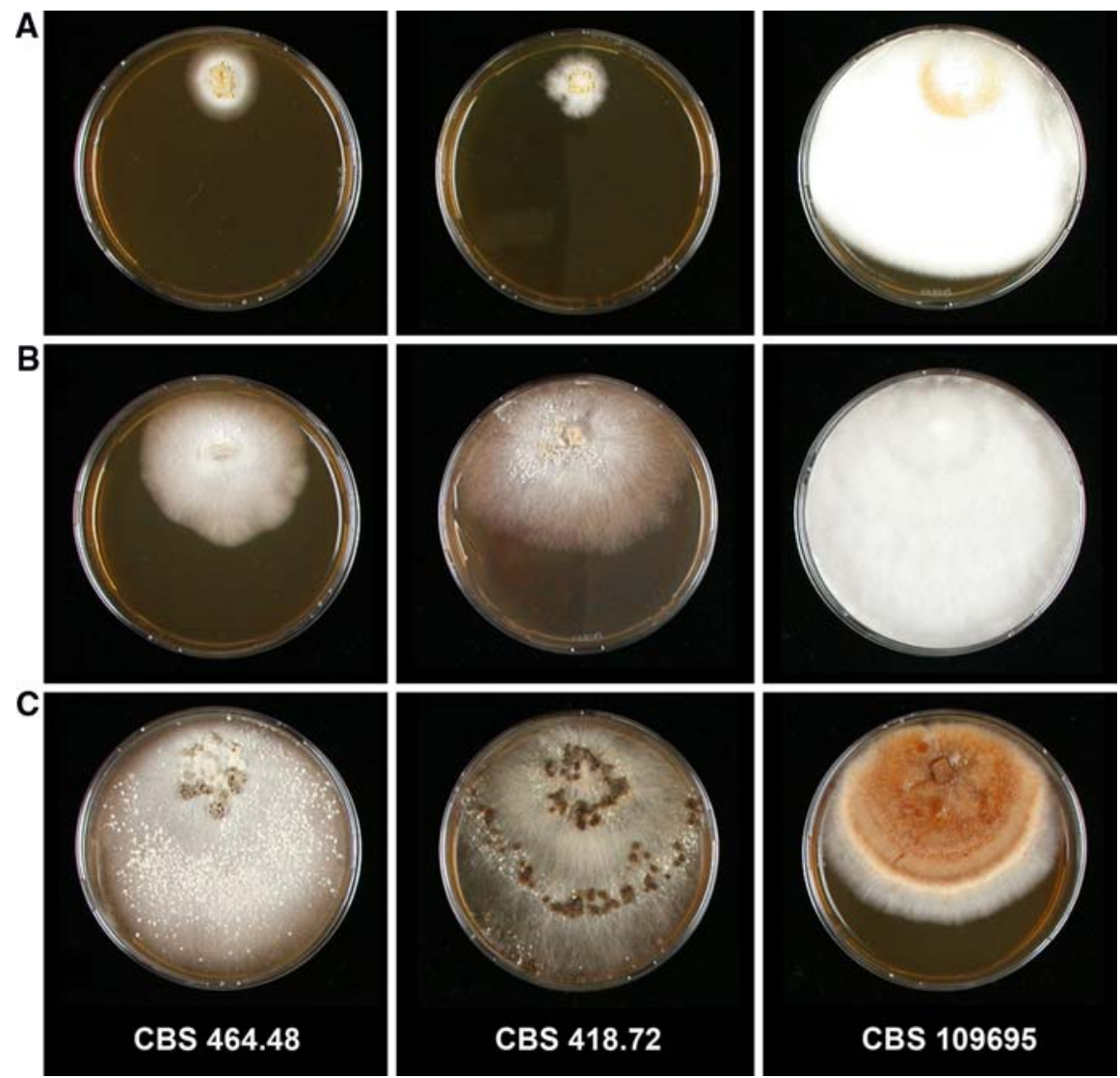

Cardinal temperatures: minimum below $-3^{\circ} \mathrm{C}$, optimum range between 9 and $12^{\circ} \mathrm{C}$, maximum $20^{\circ} \mathrm{C}$.

Holotype: CBS 109695 (IMI 395943), also preserved dried in herb. CBS.

Mycobank number: MB501325.

The sterile, sclerotium producing mycelia are traditionally classified in the artificial genus Rhizoctonia, which is currently restricted to basidiomycetous fungi and comprises anamorphs of various, not closely related genera such as Tulasnella, the Ceratobasidium-Thanatephorus complex and Athelia (Stalpers and Anderson 1996). These groups have been elevated to the genus level as Epulorhiza, Rhizoctonia s.str. and Fibulorhizoctonia. Although teleomorphs have not been observed in F. carotae and $F$. psychrophila, morphological, physiological and molecular characters indicate that $F$. psychrophila, F. carotae and Athelia arachnoidea are closely related and belong to Athelia, a corticioid genus, currently classified in the Atheliales (Rader 1948).

$F$. carotae has been described from cold stored carrots. It differs from $F$. psychrophila in growing between 18 and $27^{\circ} \mathrm{C}$ (Fig. 2), abundant production of sclerotia, and colour of the mat above $15^{\circ} \mathrm{C}$. A arachnoidea has been described from both lichens and leaf litter. It differs from $F$. psychrophila in its growth at higher temperatures (Fig. 2), less abundant aerial mycelium, and pale colour at higher temperatures. ITS sequencing of $F$. psychrophila revealed $95 \%$ identity to the ITS sequence of A. arachnoidea and A. carotae (data not shown), indicating that F. psychrophila is very closely related to these two species.

Both morphological and molecular characters indicate without doubt, that F. psychrophila, F. carotae and Athelia arachnoidea are closely related.

Temperature-tolerance and growth of $F$. psychrophila

F. psychrophila was inoculated on malt extract agar plates and incubated between 0 and $27^{\circ} \mathrm{C}$. Growth was monitored by measuring the colony diameter. Optimal growth occurred at $9-12^{\circ} \mathrm{C}$ (Fig. 2) and 


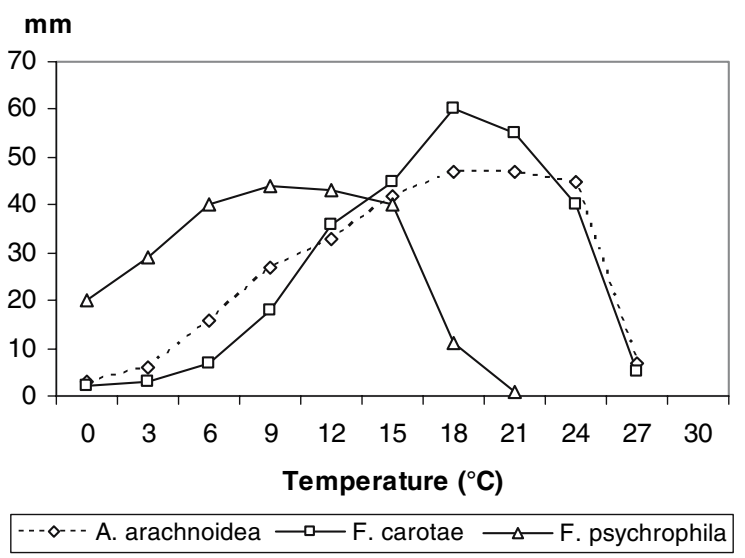

Fig. 2 Growth comparison at different temperatures of Fibulorhizoctonia psychrophila, Fibulorhizoctonia carotae and Athelia arachnoidea. The means of duplicate values are represented

growth was absent above $20^{\circ} \mathrm{C}$. When plates incubated for 3 days at 20 and $25^{\circ} \mathrm{C}$ were placed back at $15^{\circ} \mathrm{C}$ the fungus re-initiated growth, but incubation for 3 days at $32^{\circ} \mathrm{C}$ prevented growth of $F$. psychrophila after the plates were transferred to $15^{\circ} \mathrm{C}$ (data not shown). Optimal growth of $F$. carotae and $A$. arachnoidea was at between 18 and $21^{\circ} \mathrm{C}$ (Fig. 2). The strong decrease in growth of $F$. psychrophila when the incubation temperature is raised above $15^{\circ} \mathrm{C}$, suggests an even stronger adaptation of this fungus to cold biotopes.

Growth of $F$. psychrophila was tested on three vegetable crops that are commonly stored under refrigerated conditions (carrot, potato and onion) in comparison to agar plates without carbon source. Water agar alone already permits growth of $F$. psychrophila, but growth is significantly improved in the presence of carrot (data not shown). The presence of potato only resulted in a small increase in growth compared to water agar, but onion reduced growth of $F$. psychrophila. These data demonstrate a preference of F. psychrophila for carrot as a substrate. The reduced growth on onion is likely caused by the high levels of phenolic compounds in onions.

Inhibition of growth of $F$. psychrophila using antifungals

Sorbic acid and natamycin are compounds commonly used for the inhibition of growth of spoilage fungi and the effectiveness of these compounds was tested on $F$. psychrophila on malt- and water agar plates with powdered wood. F. psychrophila is believed to survive on the crates used for the storage of carrots and therefore causes repeated spoilage when these crates are re-used. The presence of $250 \mathrm{mM}$ sorbic acid resulted in a significant reduction in growth on malt extract agar, but not on powdered wood at $4^{\circ} \mathrm{C}$ (Fig. 3a). However, higher levels of sorbic acid (625
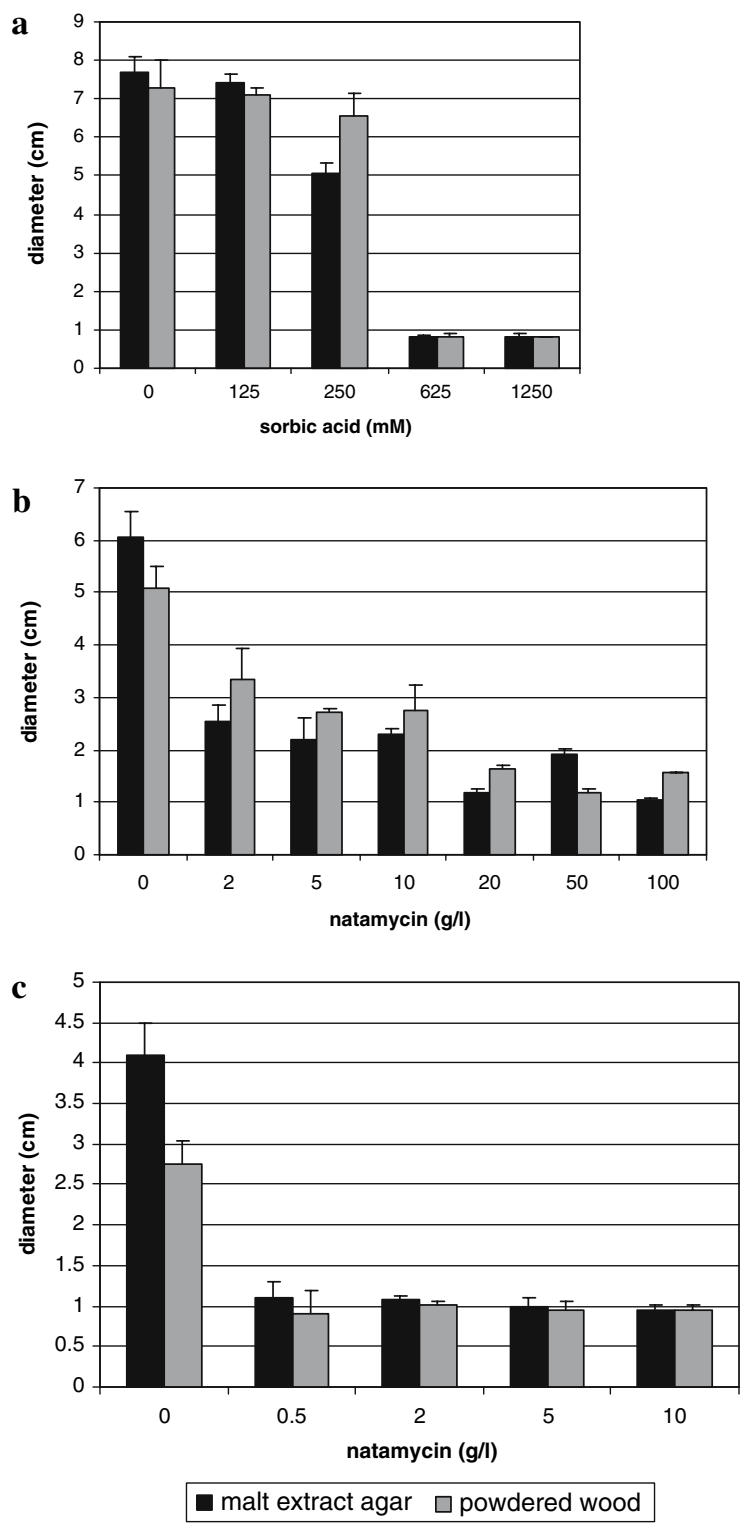

Fig. 3 Influence of antifungals on the growth of Fibulorhizoctonia psychrophila grown on malt extract agar (MA) or powdered wood from storages crates (HW). (a) sorbic acid, $18^{\circ} \mathrm{C}$; (b) natamycin, $4^{\circ} \mathrm{C}$; (c) natamycin, $18^{\circ} \mathrm{C}$ 
and $1,250 \mathrm{mM}$ ) prevented growth of $F$. psychrophila on both substrates. In light of the high concentrations of sorbic acid required to inhibit growth, the expected effectiveness of this compound in preventing spoilage by $F$. psychrophila is limited.

Natamycin was more effective in preventing growth of $F$. psychrophila, resulting in a significant decrease in growth at $2 \mathrm{~g} / \mathrm{l}$ at $4^{\circ} \mathrm{C}$. Increasing levels of natamycin reduced growth of the fungus at $4^{\circ} \mathrm{C}$ similarly on both malt extract agar and powdered wood, although a significant difference was observed at 50 and $100 \mathrm{~g} / \mathrm{l}$ (Fig. 3b). However, at $100 \mathrm{~g} / \mathrm{l}$ natamycin, some residual growth could still be observed for powdered wood. A stronger inhibition with natamycin was observed when the incubations occurred at $18^{\circ} \mathrm{C}$ instead of $4^{\circ} \mathrm{C}$, resulting in nearly complete inhibition of growth on both media at $0.5 \mathrm{~g} / 1$ natamycin (Fig. 3c). The results described here indicate that spraying wooden crates with natamycin and incubating them at $18^{\circ} \mathrm{C}$ or higher likely reduces spoilage $F$. psychrophila.

F. psychrophila produces cold-active hydrolytic enzymes during growth on polysaccharides

Both carrots and powdered wood consist largely of polysaccharides. As these are the main carbon sources for $F$. psychrophila during growth in the storage facilities, it can be expected that the fungus produces polysaccharide degrading enzymes that are active at low temperatures. To study whether these enzymes have in fact a higher relative activity at low temperatures than those currently used in industrial applications, we compared enzyme activities from F. psychrophila to those from Aspergillus niger. A. niger is one of the most commonly used fungi for the production of industrial enzyme preparations and produces a wide range of polysaccharide degrading enzymes (de Vries and Visser 2001). However, these enzymes are mainly active at higher temperatures.

For A. niger, enzyme activities dropped to 30$50 \%$ when incubation at $15^{\circ} \mathrm{C}$ was compared to $30^{\circ} \mathrm{C}$ (Fig. 4a). At $4^{\circ} \mathrm{C}$, only $10-20 \%$ of the $30^{\circ} \mathrm{C}$-activity was observed. For F. psychrophila only a 5-35\% drop was detected when comparing $30^{\circ} \mathrm{C}$ to $15^{\circ} \mathrm{C}$ and $30-60 \%$ of the activity at $30^{\circ} \mathrm{C}$ was still observed at $4^{\circ} \mathrm{C}$ (Fig. 4b). The strongest difference was observed

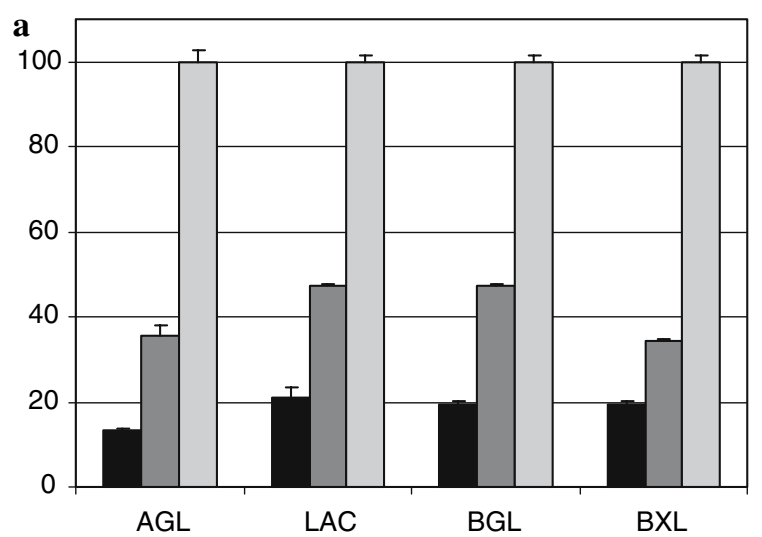

b

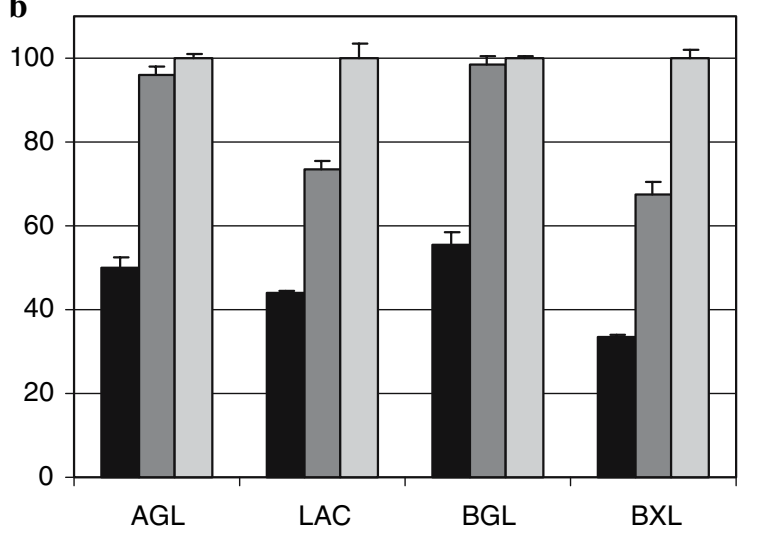

4 degrees $\square 15$ degrees $\square 30$ degrees

Fig. 4 Relative hydrolase activities in culture filtrate of Fibulorhizoctonia psychrophila and Aspergillus at different temperatures. (a) A. niger culture filtrate; (b) F. psychrophila culture filtrate. $\mathrm{AGL}=\alpha$-galactosidase, $\mathrm{LAC}=\beta$-galactosidase, $\mathrm{BGL}=\beta$-glucosidase, $\mathrm{BXL}=\beta$-xylosidase. Activity at $30^{\circ}$ is set at $100 \%$

for $\alpha$-galactosidase and $\beta$-glucosidase, where more than $90 \%$ of the activity was still detected at $15^{\circ} \mathrm{C}$ for F. psychrophila, while for A. niger only $35-45 \%$ of the activity was detected at this temperature.

$F$. psychrophila and other cold-tolerant fungi are potential sources for enzymes with high activity at low temperatures. This idea is supported by studies with cold-tolerant yeast and fungi, which were shown to produce cold-active pectinases (Nagakawa et al. 2004, 2005a, b), although in these studies a direct comparison with industrially used enzymes was not made. Cold-active enzymes can be important for many applications, for example in detergents or for the removal of lactose from milk for lactose-intolerant people. 
Open Access This article is distributed under the terms of the Creative Commons Attribution Noncommercial License which permits any noncommercial use, distribution, and reproduction in any medium, provided the original author(s) and source are credited.

\section{References}

Adams GC, Kropp BR (1996) Athelia arachnoidea, the sexual state of Rhizoctonia carotae, a pathogen of carrot in cold storage. Mycologia 88:459-472

Arvidsson L (1976) Athelia arachnoidea (Berk.) Jülich and its influence on epiphytic cryptogams in urban areas. Göteborgs Svampklubbs Årsskrift 1975-1976:4-12

Bielenin A (1986) Apple rot caused by Corticium centrifugum (Lév.) Bres. in storage. Fruit Sci Rep (Poland) 13: 143-147

Bos CJ, Debets AJM, Swart K, Huybers A, Kobus G, Slakhorst SM (1988) Genetic analysis and the construction of master strains for assignment of genes to six linkage groups in Aspergillus niger. Curr Genet 14:437-443

de Vries RP (2003) Regulation of Aspergillus genes encoding plant cell wall polysaccharide degrading enzymes; relevance for industrial production. Appl Microbiol Biotechnol 61:10-20

de Vries RP, Visser J (2001) Aspergillus enzymes involved in degradation of plant cell wall polysaccharides. Microbiol Mol Biol Rev 65:497-522

de Vries RP, Burgers K, van de Vondervoort PJI, Frisvad JC, Samson RA, Visser J (2004) A new black Aspergillus species, A. vadensis, is a promising host for homologous and heterologous protein production. Appl Environ Microbiol 70:3954-3959

Dons JJM, Springer J, de Vries SC, Wessels JGH (1979) Characterization of the genome of the basidiomycete Schizophyllum commune. Biochim Biophys Acta 563: 100-112

Hibbett DS, Binder M, Bischoff JF, Blackwell M, Cannon PF, Eriksson OE, Huhndorf S, James T et al (2007) A higherlevel phylogenetic classification of the Fungi. Mycol Res 111:509-547
Jensen A (1969) Rhizoctonia carotae Rader, a new and important disease of carrots in Denmark. Friesia 9:84-92

Jones AL, Aldwinckle HS (1990) Compendium of apple and pear diseases. APS Press, St. Paul, pp 100

Nakagawa T, Nagaoka T, Taniguchi S, Miyaji T, Tomizuka N (2004) Isolation and characterization of psychrophilic yeasts producing cold-adapted pectinolytic enzymes. Lett Appl Microbiol 38:383-387

Nakagawa T, Nagaoka T, Miyaji T, Tomizuka N (2005a) A cold-active pectin lyase from the psychrophilic and basidiomycetous yeast Cystofilobasidium capitatum strain PPY-1. Biotechnol Appl Biochem 42:193-196

Nakagawa T, Nagaoka T, Miyaji T, Tomizuka N (2005b) Coldactive polygalacturonase from psychrophilic-basidiomycetous yeast Cystofilobasidium capitatum strain PPY-1. Biosci Biotechnol Biochem 69:419-421

Panikov NS, Sivoza MV (2007) Growth kinetics of microorganisms isolated from Alaskan soil and permafrost in solid media frozen down to $-35^{\circ} \mathrm{C}$. FEMS Microbiol Ecol 59:500-512

Punja ZK (1987) Mycelial growth and pathogenesis by $R$. carotae on carrot. Can J Plant Pathol 5:24-31

Rader WE (1948) Rhizoctonia carotae n. sp. and Gliocladium aureum $\mathrm{n}$. sp., two new pathogens of carrots in cold storage. Phytopathology 38:400-452

Stalpers JA, Loerakker W (1984) Over Butlerelfia eustacei (visseoogziekte) en Auriculariopsis ampla. Coolia 27:74-81

Stalpers JA, Andersen TF (1996) A synopsis of the taxonomy of teleomorphs connected with Rhizoctonia s.1. In: Sneh B, Jabaji-Hare S, Neat S, Dijst G (eds) Rhizoctonia species: taxonomy, molecular biology, ecology, pathology and control. Kluwer, Dordrecht, pp 49-63

Weresub LK, Illman WI (1980) Corticium centrifugum reisolated from fisheye rot of stored apples. Can J Bot 58: 137-146

White TJ, Bruns T, Lee S, Taylor J (1990) Amplification and direct sequencing of fungal ribosomal RNA genes for phylogenetics. In: Innes N, Gelfand D, Sninsky J, White T (eds) PCR protocols. Academic Press, San Diego, pp 315-322 